Article

\title{
Simultaneous Determination of L- and D-Amino Acids in Proteins: A Sensitive Method Using Hydrolysis in Deuterated Acid and Liquid Chromatography-Tandem Mass Spectrometry Analysis
}

\author{
Marianne Danielsen ${ }^{1,2, *}$, Caroline Nebel $^{1}$ and Trine Kastrup Dalsgaard ${ }^{1,2,3}$ (D) \\ 1 Department of Food Science, Aarhus University, Agro Food Park 48, 8200 Aarhus N, Denmark \\ 2 CBIO, Centre for Circular Bioeconomy, Aarhus University, 8000 Aarhus C, Denmark \\ 3 iFOOD, Centre for Innovative Food Research, Aarhus University, 8000 Aarhus C, Denmark \\ * Correspondence: Marianne.Danielsen@food.au.dk
}

Received: 7 February 2020; Accepted: 5 March 2020; Published: 9 March 2020

\begin{abstract}
Determination of the L- and D-amino acid composition in proteins is important for monitoring process-induced racemization, and thereby protein quality loss, in food and feed. Such analysis has so far been challenging due to the need for sample hydrolysis, which generates racemization, thereby leading to an overestimation of D-amino acids. Here, validation of an LC-MS/MS-based method for the simultaneous determination of L- and D-amino acids in complex biological matrixes, like food and feed, was performed in combination with deuterated $\mathrm{HCl}$ hydrolysis. This approach eliminated a racemization-induced bias in the L- and D-amino acid ratios. The LC-MS/MS method was applied for the analysis of 18 free amino acids, with a quantification limit of either 12.5 or $62 \mathrm{ng} / \mathrm{mL}$, except for D-phenylalanine, for which quantification was impaired by background interference from the derivatization agent. For hydrolyzed samples, the composition of $10 \mathrm{~L}$ - and D-amino acids pairs could be determined in protein. The average relative standard deviation was $5.5 \%$ and $6.1 \%$, depending on the type of hydrolysis tubes. The method was applied on a green protein isolate (lucerne), which contained an average of $0.3 \% \mathrm{D}$-amino acids. In conclusion, this method allows for an unbiased analysis of L- and D-amino acid ratios in complex protein samples, such as food and feed.
\end{abstract}

Keywords: D-amino acid; L-amino acid; enantiomer; LC-MS/MS; protein quality; processing; racemization; hydrolysis; food; feed

\section{Introduction}

Food and feed proteins usually contain a very low amount of D-amino acids. The content of D-amino acids in feed [1] and foods can increase due to industrial processing, including; high temperature, extrusion or acid/alkaline treatment [2-4]. Fermented foods, certain health foods, and in some cases adulteration of non-fermented foods, are also known to contain higher levels of D-amino acids than fresh food [2,5-7]. In black vinegar, more than 50\% D-amino acid has been reported for certain free amino acids $[7,8]$. The presence of D-amino acids in proteins leads to impaired protein digestibility and amino acid bioavailability [4]. Not all D-amino acids are metabolized in humans or animals [9] and some D-amino acids are even toxic [10].

Over the last 80 years, the consumption of industrially processed foods has dramatically increased [11]. Elevated D-amino acid levels have been reported in products such as fruit juice 
concentrates, syrups, break-first cereals, dairy products, olives, soya protein and bacon $[2,12,13]$. Furthermore, climate changes have led to a search for alternative protein sources for food and feed (monogastrics), including insect protein and protein from green plants like white clover [14]. The protein quality of these new alternatives also needs to be investigated. Therefore, being able to reliably determine protein quality, including the D-amino acid content in food and feed, is important.

An increased interest in the roles of free D-amino acids in biology has resulted in the development of sensitive and high throughput analytical methods for detecting free D-amino acids. These include quantitative LC-MS methods combined with derivatization for enantiomeric separation [15-17]. However, analysis of the L- and D-amino acid composition in proteins remain challenging. A major point of consideration when analyzing L- and D-amino acids in complex biological samples, such as food or feed, is the need for protein hydrolysis. Alkaline or acetic hydrolysis leads to racemization, where L-amino acids are converted to D-amino acids and vice versa. This is particularly challenging as the amount of D-amino acids in these samples can be much less than $1 \%$ of the amount of L-amino acids, which means that much more L-amino acid is converted to D-amino acids than the opposite. Consequently, if not accounted for, artificially produced D-amino acids generates a bias toward the observation of more D-amino acids in hydrolyzed samples. For a recent review on the detection and quantification of D-amino acids, see Miyamoto et al. (2017) [18]. A common procedure to overcome this problem is the $0 \mathrm{~h}$ extrapolation method. As outlined by Miyamato [18]; this procedure also has shortcomings, as racemization occurring in the early stages of hydrolysis before peptide bonds are broken are not taken into account. An alternative approach is the hydrogen-deuterium exchange method [19], where proteins are hydrolyzed in deuterium chloride (DCl). If an amino acid undergoes racemization, the hydrogen on the alpha carbon becomes deuterated. Consequently, amino acids or peptides undergoing racemization increase by $+1 \mathrm{Da}$ in mass and will therefore not be included in the analysis.

We have developed and validated a sensitive LC-MS/MS method for the analysis of 18 free proteogenic amino acids. Combined with hydrolysis using $\mathrm{DCl}$, the method allowed for simulations determination of $10 \mathrm{~L}$ - and D-amino acids pairs in protein. In this method, hydrogen-deuterium exchange during hydrolysis results in a +1 Da in mass increase in amino acids or peptides undergoing racemization $[19,20]$. This means that the unbiased relative ratio between non-deuterated L- and D-amino acid can be determined in complex biological samples. We show that this method can be applied for both small volumes of liquid and for solid samples, such as food and feed. The method was used to analyze L- and D-amino acids in a protein concentrate from lucerne; a plant protein alternative to animal protein, which has a lower climate impact.

\section{Materials and Methods}

\subsection{Chemicals, Reagents and Materials}

L- and D-amino acid standards were obtained from Sigma-Aldrich (Darmstadt, Germany). Internal standards were purchased as a "cell-free" amino acid mix of 20 stable isotope-labeled amino acids (Cambridge Isotope Laboratories Inc., Andover, MA, USA). The chiral derivatization agent (S)-N-(4-nitrophenoxycarbonyl) phenylalanine methoxyethyl ester (S-NIFE) was obtained from Santa Cruz Biotechnology (Dallas, TX, USA). All solvents for LC-MS analysis were hypergrade (Merch, Darmstadt, Germany). Amino acid standard H (ThermoFisher Scientific, Waltham, MA, USA), an 18 amino acid mix, was used as QC sample. Milli-Q water was used throughout the experiments (Millipore, Darmstadt, Germany).

\subsection{Standard Solutions and Calibration Standards}

Stock solutions of all L- and D-amino acids were prepared individually $(1 \mathrm{mg} / \mathrm{mL})$ in the following solvents; ethanol:water (50:50, v/v) (arginine, 4-hydroxyproline, valine, leucine, histidine, lysine, proline, serine, alanine, glycine, phenylalanine, isoleucine), water (aspartic acid, glutamic acid, methionine) 
and $70 \mathrm{mM} \mathrm{NaOH}$ (tyrosine, threonine, tryptophan). Mixed standard solutions were further diluted with ethanol:water $(50: 50, v / v)$ to obtain working solutions at 11 different concentration levels $(0,1.25$, $12.5,125,625,1250,6250,12,500,25,000,37,500$ and 50,000 ng/mL). Internal standard (IS) mix solution was also prepared at $1 \mathrm{mg} / \mathrm{mL}$ in ethanol:water $(50: 50, v / v)$. IS was added to calibration standards, QC and analytical samples in the ratio 1:4 (IS:sample). All solutions were kept at $-80^{\circ} \mathrm{C}$ until use.

\subsection{Protein Hydrolysis}

Protein hydrolysis was performed in either glass capillary tubes (ideal for small volumes of liquid or fine powders) or vacuum hydrolysis tubes (ideal for other types of food or feed).

\subsubsection{Glass Capillary Tubes}

For hydrolysis in glass capillary tubes, dimensions of $150 \times 2.35 \mathrm{~mm}$ (Hirchmann, Eberstadt, Germany) was used. After closing one end of the glass capillary tube using a gas flame, sample was added as either a powder (protein concentrate from lucerne) or a liquid. Liquids were then evaporated to dryness using a vacuum centrifuge. Then, $40 \mu \mathrm{L}$ of hydrolysis solution consisting of $\mathrm{DCl}(20 \mathrm{wt} \%$ solution in $\mathrm{D} 2 \mathrm{O}$, Acros organics, New Jersey, USA) $+1 \%$ mecaptoethanol and 3\% phenol [21] was added to the tubes. The headspace was flushed with argon for $20 \mathrm{~s}$ and the capillary was quickly transferred into a gas flame to close the tube to limit the amount of oxygen.

\subsubsection{Vacuum Hydrolysis Tubes}

For hydrolysis in vacuum hydrolysis tubes (Vacuum Hydrolysis Tube, $1 \mathrm{~mL}$, Thermo Scientific, IL, USA) sample was added to the bottom of the tube and $200 \mu \mathrm{L}$ hydrolysis liquid was added. The sample was snap-frozen in liquid nitrogen, vacuum was applied to the tube and the tube was carefully closed.

All samples (both glass capillary and hydrolysis tubes) were hydrolyzed at $110^{\circ} \mathrm{C}$ for $20 \mathrm{~h}$. Heavy labeled internal amino acid standards (mix of 20 amino acids) were added after hydrolysis. After hydrolysis, samples were centrifuged and the supernatant was evaporated to dryness and re-dissolved in either $40 \mu \mathrm{L}$ or $200 \mu \mathrm{L}$ ethanol:water (50:50, $v / v)$, respectively.

\subsection{Sample Derivatization}

Samples were derivatized by mixing $10 \mu \mathrm{L}$ of sample with $7 \mu \mathrm{L} 0.15 \mathrm{M}$ sodium tetraborate and $10 \mu \mathrm{L} 2.5 \mathrm{mg} / \mathrm{mL}$ (S)-NIFE in acetonitrile. The mixture was vortexed and incubated for $20 \mathrm{~min}$. At this step, the reaction solution was expected to appear yellow ( $\mathrm{pH}$ approx. 8). Undiluted hydrolyzed samples may be too acidic. In this case, more sodium tetraborate was added and the volume of $\mathrm{H}_{2} \mathrm{O}$ used for quenching was reduced, respectively. The reaction was quenched by adding $2 \mu \mathrm{L} 4 \mathrm{M} \mathrm{HCl}$ and $71 \mathrm{uL} \mathrm{H}_{2} \mathrm{O}$. This procedure was adapted from $[15,16]$.

\subsection{LC-MS/MS Instrumentation and Optimization}

LC-MS/MS analysis was performed on a triple quadrupole tandem mass spectrometer (6460 TripleQuad LC/MS, Agilent Technologies, Santa Clara, CA, USA) coupled to a 1290 Infinity LC system (Agilent Technologies, Santa Clara, CA, USA). Chromatographic separation was carried out on a Luna Omega C18 column $(100 \times 2.1 \mathrm{~mm}, 1.6 \mu \mathrm{m}, 100 \AA)$ (Phenomenex, Torrance, CA, USA) at $40^{\circ} \mathrm{C}$. Mobile phases were (A) $5 \%$ acetic acid in water and (B) $10 \%$ methanol in acetonitrile [15,16]. The LC gradient was $\mathrm{t}(\mathrm{min}) / \mathrm{B}(\%) ; 0 / 5,25 / 50,27 / 98,29 / 98,29.1 / 5$ and $40 / 5$ operated at a flow rate of $0.25 \mathrm{~mL} / \mathrm{min}$. The injection volume was $2 \mu \mathrm{L}$.

Triple quadrupole MS conditions for analyzing S-NIFE derivatized L- and D- amino acids and the stable isotope-labeled IS were optimized in positive ion mode using multiple reaction monitoring (MRM). First, source parameter settings were optimized by injecting 3 amino acid standards: arginine, serine and phenylalanine. Optimization was achieved by injecting standards at multiple source parameter increments. The following source parameters were used: gas temperature, $350^{\circ} \mathrm{C}$; gas flow, 
$8 \mathrm{~L} / \mathrm{min}$; nebulizer, $15 \mathrm{psi}$; sheath gas temperature, $350^{\circ} \mathrm{C}$; sheath gas flow, $11 \mathrm{~L} / \mathrm{min}$; capillary voltage (positive mode) $3000 \mathrm{~V}$; nozzle voltage (positive mode), $1500 \mathrm{~V}$.

Then, collision voltage (CV) and fragmentor voltage were optimized for quantifier and qualifier ions for all amino acids and there IS using direct injection and the Agilent Optimizer software, version B.08.00, built 8.0.8023.0. MRM transitions were modified from Visser et al. [15] using different stable isotope-labeled standards and with quantifier and qualifier ions optimized for our instrument. The MRM transitions, parameter settings and retention times are listed in Table 1.

Table 1. Multiple reaction monitoring (MRM) parameters, fragmentor voltage, collision energy and retention time.

\begin{tabular}{|c|c|c|c|c|c|c|c|}
\hline Analyte & $\begin{array}{l}\text { Precursor } \\
\text { Ion }\end{array}$ & $\begin{array}{l}\text { Quantifier } \\
\text { Ion }\end{array}$ & $\begin{array}{l}\text { Qualifier } \\
\text { Ion }\end{array}$ & $\begin{array}{l}\text { Fragmentor } \\
\text { Voltage }\end{array}$ & $\begin{array}{c}\text { Collision } \\
\text { Energy }\end{array}$ & $\begin{array}{c}\text { Retention } \\
\text { Time, L }\end{array}$ & $\begin{array}{c}\text { Retention } \\
\text { Time, D }\end{array}$ \\
\hline \multirow[t]{2}{*}{ Glycine } & 324.9 & 224.0 & & 90 & 4 & 14.96 & \\
\hline & & & 119.9 & 90 & 20 & & \\
\hline \multirow[t]{2}{*}{ Glycine IS } & 327.9 & 224.0 & & 90 & 4 & & \\
\hline & & & 119.9 & 90 & 20 & & \\
\hline \multirow[t]{2}{*}{ Alanine } & 339.1 & 224.0 & & 90 & 4 & 16.00 & 17.65 \\
\hline & & & 120.0 & 90 & 20 & & \\
\hline \multirow[t]{2}{*}{ Alanine IS } & 343.1 & 120.0 & & 90 & 4 & & \\
\hline & & & 224.0 & 90 & 20 & & \\
\hline \multirow{2}{*}{ Valine } & 367.2 & 224.0 & & 110 & 40 & 20.32 & 22.46 \\
\hline & & & 120.0 & 90 & 8 & & \\
\hline \multirow[t]{2}{*}{ Valine IS } & 373.2 & 224.0 & & 90 & 8 & & \\
\hline & & & 120.0 & 90 & 24 & & \\
\hline \multirow[t]{2}{*}{ Leucine } & 381.1 & 224.0 & & 90 & 8 & 23.24 & 25.09 \\
\hline & & & 120.0 & 90 & 28 & & \\
\hline \multirow[t]{2}{*}{ Leucine IS } & 388.1 & 224.0 & & 90 & 8 & & \\
\hline & & & 120.0 & 90 & 28 & & \\
\hline \multirow[t]{2}{*}{ Isoleucine } & 381.1 & 224.0 & & 90 & 24 & 22.83 & 24.86 \\
\hline & & & 120.0 & 90 & 8 & & \\
\hline \multirow[t]{2}{*}{ Isoleucine IS } & 388.1 & 224.0 & & 90 & 24 & & \\
\hline & & & 120.0 & 90 & 8 & & \\
\hline \multirow{2}{*}{ Methionine } & 399.0 & 149.9 & & 90 & 12 & 20.65 & 22.24 \\
\hline & & & 120.0 & 90 & 24 & & \\
\hline \multirow[t]{2}{*}{ Methionine IS } & 405.0 & 224.0 & & 90 & 12 & & \\
\hline & & & 155.9 & 90 & 12 & & \\
\hline \multirow[t]{2}{*}{ Phenylalanine } & 415.1 & 166.0 & & 90 & 8 & 24.37 & 25.79 \\
\hline & & & 120.0 & 90 & 32 & & \\
\hline \multirow[t]{2}{*}{ Phenylalanine IS } & 425.1 & 224.0 & & 90 & 8 & & \\
\hline & & & 120.0 & 90 & 20 & & \\
\hline \multirow{2}{*}{ Tryptophan } & 454.1 & 188.0 & & 90 & 24 & 24.31 & 25.45 \\
\hline & & & 120.0 & 90 & 28 & & \\
\hline \multirow[t]{2}{*}{ Tryptophan IS } & 467.1 & 224.0 & & 90 & 30 & & \\
\hline & & & 120.0 & 90 & 30 & & \\
\hline \multirow[t]{2}{*}{ Proline } & 365.1 & 120.0 & & 90 & 24 & 18.27 & 19.10 \\
\hline & & & 114.0 & 90 & 28 & & \\
\hline \multirow[t]{2}{*}{ Proline IS } & 371.1 & 295.0 & & 90 & 8 & & \\
\hline & & & 120.0 & 90 & 24 & & \\
\hline \multirow[t]{2}{*}{ 4-hydroxy proline } & 380.9 & 131.9 & & 90 & 12 & 13.41 & \\
\hline & & & 120.0 & 90 & 24 & & \\
\hline \multirow[t]{2}{*}{ Serine } & 355.0 & 224.1 & & 90 & 8 & 14.07 & 14.32 \\
\hline & & & 120.0 & 90 & 24 & & \\
\hline \multirow[t]{2}{*}{ Serine IS } & 359.0 & 224.1 & & 90 & 8 & & \\
\hline & & & 120.0 & 90 & 24 & & \\
\hline Threonine & 369.1 & 224.0 & & 90 & 12 & 16.32 & 14.99 \\
\hline & & & 120.0 & 90 & 24 & & \\
\hline Threonine IS & 374.1 & 224.0 & & 90 & 12 & & \\
\hline & & & 120.0 & 90 & 12 & & \\
\hline Tyrosine & 680.2 & 224.0 & & 110 & 20 & 29.91 & 30.05 \\
\hline & & & 120.0 & 110 & 40 & & \\
\hline
\end{tabular}


Table 1. Cont.

\begin{tabular}{|c|c|c|c|c|c|c|c|}
\hline Analyte & $\begin{array}{l}\text { Precursor } \\
\text { Ion }\end{array}$ & $\begin{array}{l}\text { Quantifier } \\
\text { Ion }\end{array}$ & $\begin{array}{l}\text { Qualifier } \\
\text { Ion }\end{array}$ & $\begin{array}{l}\text { Fragmentor } \\
\text { Voltage }\end{array}$ & $\begin{array}{c}\text { Collision } \\
\text { Energy }\end{array}$ & $\begin{array}{c}\text { Retention } \\
\text { Time, L }\end{array}$ & $\begin{array}{c}\text { Retention } \\
\text { Time, D }\end{array}$ \\
\hline \multirow[t]{2}{*}{ Tyrosine IS } & 690.2 & 224.0 & & 110 & 60 & & \\
\hline & & & 120.0 & 110 & 60 & & \\
\hline \multirow[t]{2}{*}{ Aspartic acid } & 383.1 & 133.9 & & 90 & 8 & 14.58 & 15.18 \\
\hline & & & 120.0 & 90 & 32 & & \\
\hline \multirow[t]{2}{*}{ Aspartic acid IS } & 388.1 & 224.0 & & 90 & 20 & & \\
\hline & & & 139.0 & 90 & 8 & & \\
\hline \multirow{2}{*}{ Glutamic acid } & 397.1 & 147.9 & & 90 & 12 & 15.09 & 15.63 \\
\hline & & & 120.0 & 90 & 28 & & \\
\hline \multirow[t]{2}{*}{ Glutamic acid IS } & 403.1 & 224.0 & & 90 & 12 & & \\
\hline & & & 154.1 & 90 & 12 & & \\
\hline \multirow[t]{2}{*}{ Lysine } & 645.2 & 224.0 & & 130 & 52 & 26.90 & 27.25 \\
\hline & & & 120.0 & 130 & 52 & & \\
\hline \multirow[t]{2}{*}{ Lysine IS } & 653.2 & 224.0 & & 130 & 52 & & \\
\hline & & & 120.0 & 130 & 52 & & \\
\hline \multirow[t]{2}{*}{ Arginine } & 424.2 & 201.0 & & 130 & 20 & 12.14 & 11.95 \\
\hline & & & 175.0 & 130 & 20 & & \\
\hline \multirow[t]{2}{*}{ Arginine IS } & 434.2 & 211.0 & & 130 & 30 & & \\
\hline & & & 185.0 & 130 & 40 & & \\
\hline \multirow[t]{2}{*}{ Histidine } & 405.0 & 182.0 & & 90 & 12 & 11.41 & 10.21 \\
\hline & & & 110.0 & 90 & 36 & & \\
\hline \multirow[t]{2}{*}{ Histidine IS } & 414.0 & 224.0 & & 90 & 28 & & \\
\hline & & & 120.0 & 90 & 28 & & \\
\hline
\end{tabular}

\subsection{Method Validation}

The method was validated in terms of linearity, lower and upper limit of quantification (LLOQ and ULOQ), stability, carry-over and with-in and between-run precision. These parameters were validated according to Guideline on bioanalytical method validation (European Medicines Agency, EMEA/CHMP/192217/2009 rev. 1 Corr. 2). Furthermore, the matrix effect and recovery after hydrolysis was evaluated.

\subsection{Linearity and Limit of Quantification}

Calibration curves ranging from 0 to $1250 \mathrm{ng} / \mathrm{mL}$ and 1250 to $50,000 \mathrm{ng} / \mathrm{mL}$ with a total of 11 calibration points were established to cover the wide range of analysis. The linear equation and the regression coefficient was obtained from an average of 3 calibration curves (individually processed from 2 individually prepared standard curve mixtures). The limit of quantification (LOQ) was established by the criteria, that the individual calibration points on the standard curve should have an accuracy of $\pm 20 \%$ relative to the linear equation.

\subsection{Stability and Carry-Over}

Stability of the derivatized samples was evaluated by injecting the same sample every 12 hours over a $72 \mathrm{~h}$ period. The samples were left in the temperature-controlled autosampler at $20^{\circ} \mathrm{C}$.

Carry-over was investigated by running a MilliQ-water sample right after a calibration curve sample with the highest concentration $(50,000 \mathrm{ng} / \mathrm{mL})$.

\subsection{With-In Run Accuracy and Between-Run Accuracy}

To establish the with-in run and between-run accuracy, 3 identical samples for each of 4 concentration levels were made. The concentration levels spanned the entire range of analysis, with 2 concentrations points on the lower range curve, approx. LLOQ and $3 \times L L O Q(100 \mathrm{ng} / \mathrm{mL}$ and $300 \mathrm{ng} / \mathrm{mL}$ ) and with 2 concentration points on the higher range curve at approx. $30 \%$ and $75 \%$ of ULOQ $(15,000 \mathrm{ng} / \mathrm{mL}$ and $35,000 \mathrm{ng} / \mathrm{mL})$. Four days later, new derivatization of the samples was made. These samples were analyzed on a new calibration curve prepared that day. 


\subsection{Recovery and Matrix Effect}

Recovery was evaluated by hydrolyzing an amino acid mix with concentrations equivalent to two calibration points $(6250 \mathrm{ng} / \mathrm{mL}$ and $25,000 \mathrm{ng} / \mathrm{mL})$ in capillary tubes without IS. After hydrolysis, IS was added and the samples were analyzed on a regular standard curve without hydrolysis. The matrix effect of hydrolyzed protein was evaluated by spike-in of $12,500 \mathrm{ng}$ of standard amino acid mix into hydrolyzed $\alpha$-lactalbumin (capillary tubes, $10 \mu \mathrm{g} / \mathrm{mL} \alpha$-lactalbumin, $n=5$ ).

\section{Results}

\subsection{Optimizing LC-MS Source Parameters}

In order to obtain high sensitivity, the mass spectrometry source parameters were optimized to our instrumentation using three different amino acids representing different physical properties of amino acids. This optimization resulted in a 4.5, 6.8 and 8.0 times signal increase for phenylalanine, arginine and serine, respectively. Mass spectrometry parameter settings are shown in Table 1.

\subsection{Method Validation}

The LC-MS/MS method was validated according to the description in materials and methods, Section 2.6.

\subsubsection{Linearity and Limit of Quantification}

Linearity and limit of quantification were determined for a low range calibration curve $(0-1250 \mathrm{ng} / \mathrm{mL})$ and a high range calibration curve (1250-50,000 ng/mL). The linear regression coefficients, linear equations as well as LLOQ and ULOQ are listed in Table 2.

The LLOQ and ULOQ were defined as the lower and upper calibration points, which were less than $\pm 20 \%$ off, relative to the linear equation (e.g., the calibration point $12.5 \mathrm{ng} / \mathrm{mL} \pm 2.5 \mathrm{ng} / \mathrm{mL}$ ). The ULOQ was equal to the highest calibration point $(50,000 \mathrm{ng} / \mathrm{mL})$ for all analytes, whereas the LLOQ was either $12.5 \mathrm{ng} / \mathrm{mL}$ or $62.5 \mathrm{ng} / \mathrm{mL}$ for all analytes, except phenylalanine. We observed a low baseline signal from all analytes in blank derivatized samples. In contrast, we saw a very strong background signal from phenylalanine. Consequently, we were unable to establish a linear phenylalanine calibration curve for calibration points below 12,500 ng/mL.

Table 2. Linearity and limit of quantification.

\begin{tabular}{|c|c|c|c|c|c|c|}
\hline Analyte & $\begin{array}{c}\text { Linearity, } \\
R^{2}(0-1250 \\
\mathrm{ng} / \mathrm{mL})\end{array}$ & $\begin{array}{l}\text { Linear Equation } \\
(0-1250 \mathrm{ng} / \mathrm{mL})\end{array}$ & $\begin{array}{c}\text { Linearity, } R^{2} \\
(1250-50,000 \\
n g / m L)\end{array}$ & $\begin{array}{l}\text { Linear Equation } \\
(1250-50,000 \mathrm{ng} / \mathrm{mL})\end{array}$ & $\begin{array}{c}\text { LLOQ } \\
\text { (ng/mL) }\end{array}$ & $\begin{array}{c}\text { ULOQ } \\
\text { (ng/mL) }\end{array}$ \\
\hline Glycine & 0.998 & $y=0.000177 x-0.000077$ & 0.999 & $y=0.000187 x-0.037257$ & 12.5 & 50,000 \\
\hline Alanine & 0.998 & $y=0.000088 x-0.000107$ & 0.999 & $y=0.000095 x-0.024423$ & 12.5 & 50,000 \\
\hline Valine & 0.998 & $y=0.000086 x-0.000316$ & 0.999 & $y=0.000092 x-0.024619$ & 12.5 & 50,000 \\
\hline Leucine & 0.993 & $y=0.000063 x+0.000860$ & 0.999 & $y=0.000084 x-0.029608$ & 62.5 & 50,000 \\
\hline Isoleucine & 0.999 & $y=0.000102 x-0.000440$ & 0.999 & $y=0.000110 x-0.03335$ & 12.5 & 50,000 \\
\hline Methionine & 0.998 & $y=0.000793 x-0.005627$ & 0.998 & $y=0.000879 x-0.318433$ & 12.5 & 50,000 \\
\hline Phenylalanine & - & - & 0.989 & $y=0.001942 x+0.939886$ & 12,500 & 50,000 \\
\hline Tryptophan & 0.998 & $\mathrm{y}=0.000306 \mathrm{x}-0.001744$ & 0.999 & $y=0.000338 x-0.083823$ & 12.5 & 50,000 \\
\hline Proline & 0.998 & $y=0.000322 x-0.002019$ & 0.994 & $y=0.003575 x-0.36016$ & 12.5 & 50,000 \\
\hline 4-hydroxy proline & 0.995 & $y=0.000128 x-0.000996$ & 0.990 & $\mathrm{y}=0.000135 \mathrm{x}-0.059385$ & 12.5 & 50,000 \\
\hline Serine & 0.997 & $y=0.000232 x+0.00150$ & 0.999 & $y=0.000258 x-0.078782$ & 12.5 & 50,000 \\
\hline Threonine & 0.998 & $\mathrm{y}=0.000567 \mathrm{x}-0.002145$ & 0.999 & $y=0.000597 x-0.089318$ & 12.5 & 50,000 \\
\hline Tyrosine & 0.991 & $\mathrm{y}=0.000190 \mathrm{x}-0.00170$ & 0.984 & $y=0.000209 x+0.001621$ & 62.5 & 50,000 \\
\hline Aspartic acid & 0.995 & $y=0.001266 x-0.008566$ & 0.999 & $y=0.001401 x-0.443840$ & 62.5 & 50,000 \\
\hline Glutamic acid & 0.996 & $y=0.000189 x-0.001074$ & 0.998 & $y=0.000208 x-0.062358$ & 12.5 & 50,000 \\
\hline Lysine & 0.995 & $\mathrm{y}=0.000049 \mathrm{x}-0.000379$ & 0.999 & $y=0.000055 x-0.015241$ & 62.5 & 50,000 \\
\hline Arginine & 0.995 & $\mathrm{y}=0.000149 \mathrm{x}-0.001611$ & 0.999 & $\mathrm{y}=0.000160 \mathrm{x}-0.048739$ & 62.5 & 50,000 \\
\hline Histidine & 0.999 & $y=0.018330 x-0.080064$ & 0.999 & $y=0.019683 x-5.175752$ & 12.5 & 50,000 \\
\hline
\end{tabular}

\subsubsection{Stability and Carry-Over}

The derivatized samples were tested for stability. Table 3 lists the relative standard deviation in percent (\%RSD) for a $72 \mathrm{~h}$ stability test, with injections every 12 hours. The \%RSD was well below $3.5 \%$ 
for all amino acids, showing that the derivatized samples are stable for a three-day period at $20{ }^{\circ} \mathrm{C}$ in the autosampler. Carry-over was hardly detectable and far below the threshold of $20 \%$ of LLOQ (data not shown).

Table 3. Method stability, within-run and between-run precision.

\begin{tabular}{|c|c|c|c|c|}
\hline Analyte & $\begin{array}{l}\text { Method Stability } \\
0-72 \text { h, \%RSD }{ }^{1, *}\end{array}$ & $\begin{array}{l}\text { Concentration } \\
(\mathrm{ng} / \mathrm{mL})^{2}\end{array}$ & $\begin{array}{l}\text { Within-Run } \\
\text { \%RSD }^{2, *}\end{array}$ & $\begin{array}{c}\text { Between-Run } \\
4 \text { Days, \%RSD }{ }^{2, *}\end{array}$ \\
\hline \multirow[t]{4}{*}{ Glycine } & 1.25 & 100 & 3.02 & 2.36 \\
\hline & & 300 & 2.94 & 3.65 \\
\hline & & 15.000 & 1.38 & 1.22 \\
\hline & & 35.000 & 1.32 & 0.89 \\
\hline \multirow[t]{4}{*}{ Alanine } & 0.81 & 100 & 1.02 & 1.56 \\
\hline & & 300 & 1.77 & 1.80 \\
\hline & & 15.000 & 1.26 & 0.87 \\
\hline & & 35.000 & 0.45 & 1.19 \\
\hline \multirow[t]{4}{*}{ Valine } & 0.93 & 100 & 2.00 & 2.20 \\
\hline & & 300 & 3.19 & 3.04 \\
\hline & & 15.000 & 0.95 & 0.94 \\
\hline & & 35.000 & 0.23 & 1.20 \\
\hline \multirow[t]{4}{*}{ Leucine } & 0.76 & 100 & 2.07 & 1.63 \\
\hline & & 300 & 2.55 & 2.61 \\
\hline & & 15.000 & 1.20 & 1.20 \\
\hline & & 35.000 & 2.54 & 1.48 \\
\hline \multirow[t]{4}{*}{ Isoleucine } & 0.81 & 100 & 1.95 & 1.49 \\
\hline & & 300 & 3.10 & 3.12 \\
\hline & & 15.000 & 1.03 & 0.93 \\
\hline & & 35.000 & 0.43 & 1.61 \\
\hline \multirow[t]{4}{*}{ Methionine } & 1.35 & 100 & 1.32 & 1.50 \\
\hline & & 300 & 2.22 & 3.06 \\
\hline & & 15.000 & 0.68 & 0.56 \\
\hline & & 35.000 & 0.29 & 1.33 \\
\hline \multirow[t]{4}{*}{ Phenylalanine } & - & 100 & - & - \\
\hline & & 300 & - & - \\
\hline & & 15.000 & 3.06 & 17.95 \\
\hline & & 35.000 & 2.00 & 5.62 \\
\hline \multirow[t]{4}{*}{ Tryptophan } & 1.05 & 100 & 2.26 & 2.68 \\
\hline & & 300 & 3.40 & 4.88 \\
\hline & & 15.000 & 1.11 & 0.78 \\
\hline & & 35.000 & 0.88 & 0.94 \\
\hline \multirow[t]{4}{*}{ Proline } & 0.86 & 100 & 3.19 & 1.00 \\
\hline & & 300 & 0.95 & 2.25 \\
\hline & & 15.000 & 0.23 & 1.40 \\
\hline & & 35.000 & 2.07 & 5.44 \\
\hline \multirow[t]{4}{*}{ 4-hydroxy proline } & 1.90 & 100 & 1.84 & 6.97 \\
\hline & & 300 & 2.88 & 3.74 \\
\hline & & 15.000 & 2.55 & 3.91 \\
\hline & & 35.000 & 3.06 & 6.93 \\
\hline \multirow[t]{4}{*}{ Serine } & 1.36 & 100 & 2.05 & 2.86 \\
\hline & & 300 & 1.46 & 4.56 \\
\hline & & 15.000 & 0.84 & 0.76 \\
\hline & & 35.000 & 1.07 & 1.91 \\
\hline
\end{tabular}


Table 3. Cont.

\begin{tabular}{|c|c|c|c|c|}
\hline Analyte & $\begin{array}{l}\text { Method Stability } \\
0-72 \text { h, \%RSD }{ }^{1, *}\end{array}$ & $\begin{array}{c}\text { Concentration } \\
(\mathrm{ng} / \mathrm{mL})^{2}\end{array}$ & $\begin{array}{l}\text { Within-Run } \\
\text { \%RSD }^{2, *}\end{array}$ & $\begin{array}{c}\text { Between-Run } \\
4 \text { Days, \%RSD }{ }^{2, *}\end{array}$ \\
\hline \multirow[t]{4}{*}{ Threonine } & 1.78 & 100 & 2.59 & 5.29 \\
\hline & & 300 & 3.55 & 2.63 \\
\hline & & 15.000 & 0.73 & 0.83 \\
\hline & & 35.000 & 0.19 & 1.53 \\
\hline \multirow[t]{4}{*}{ Tyrosine } & 1.00 & 300 & 2.75 & 2.75 \\
\hline & & 400 & 5.00 & 5.00 \\
\hline & & 15.000 & 0.62 & 6.34 \\
\hline & & 35.000 & 1.01 & 7.44 \\
\hline \multirow[t]{4}{*}{ Aspartic acid } & 3.44 & 100 & 4.07 & 4.10 \\
\hline & & 300 & 3.34 & 4.22 \\
\hline & & 15.000 & 1.20 & 1.40 \\
\hline & & 35.000 & 1.64 & 2.03 \\
\hline \multirow[t]{4}{*}{ Glutamic acid } & 2.07 & 100 & 2.56 & 3.59 \\
\hline & & 300 & 2.36 & 2.18 \\
\hline & & 15.000 & 1.42 & 1.210 \\
\hline & & 35.000 & 0.61 & 1.15 \\
\hline \multirow[t]{4}{*}{ Lysine } & 1.00 & 100 & 1.77 & 2.11 \\
\hline & & 300 & 1.26 & 1.77 \\
\hline & & 15.000 & 0.45 & 0.67 \\
\hline & & 35.000 & 1.84 & 1.49 \\
\hline \multirow[t]{4}{*}{ Arginine } & 0.68 & 100 & 2.54 & 2.21 \\
\hline & & 300 & 3.28 & 2.50 \\
\hline & & 15.000 & 1.23 & 0.90 \\
\hline & & 35.000 & 0.86 & 1.75 \\
\hline \multirow[t]{4}{*}{ Histidine } & 2.32 & 100 & 3.28 & 3.47 \\
\hline & & 300 & 1.23 & 2.83 \\
\hline & & 15.000 & 0.86 & 2.64 \\
\hline & & 35.000 & 1.02 & 1.95 \\
\hline
\end{tabular}

${ }^{1}$ From 0 to $72 \mathrm{~h}, 12 \mathrm{~h}$ intervals, $n=7 .{ }^{2}$ Four concentrations for each analyte, $n=3 .{ }^{*}$ Relative standard deviation in percent (\%RSD).

\subsubsection{With-In and Between-Run Precision}

The with-in run and between-run precision (\%RSD) for each of the four concentrations is also listed in Table 3. The with-in run precision was $\leq 5 \%$ RSD for all analytes, whereas the between-run precision was $\leq 7.5 \%$ RSD for all analytes. One exception was phenylalanine, where we observed a decrease in the between-run precision for the $15,000 \mathrm{ng} / \mathrm{mL}$ calibration point (17.9\%RSD), due to the high background signal for phenylalanine (see Section 3.2.1).

\subsection{Optimization of Sample Hydrolysis}

\subsubsection{Matrix Effect and Recovery of Hydrolyzed Samples}

In order to evaluate the matrix effect of hydrolyzed protein, we made a spike-in of $12,500 \mathrm{ng}$ of each amino acid standard into a solution of a hydrolyzed pure protein. We chose $\alpha$-lactalbumin, as it has an amino acid composition consisting of all the amino acids we are analyzing for, with the exception of 4-hydroxy-proline. Table 4 shows the recovery $(n=5)$ and the \%RSD. In general, we see a slight overestimation $(4.1 \%-9.1 \%)$ for all amino acids. One exception is 4 -hydroxy proline $(2.5 \%$ underestimation), which is not present in the matrix. The $\%$ RSD was $\leq 5.2 \%$. These results indicate that there is a minor matrix effect of hydrolyzed protein.

The recovery after hydrolysis was evaluated by hydrolyzing samples from two standard point concentrations: $625 \mathrm{ng} / \mathrm{mL}$ (low-level standard curve) and 25,000 ng/mL (high-level standard curve). 
After hydrolysis, internal standard was added and the samples were analyzed on the regular standard curves. The results are also shown in Table 4. The data show that for most amino acids there is a recovery of approx. $80 \%-90 \%$ after protein hydrolysis.

Table 4. Recovery after spike-in and recovery after hydrolysis.

\begin{tabular}{|c|c|c|c|c|}
\hline Analyte & $\begin{array}{l}\text { Recovery, } \% \\
\text { Spike-in }{ }^{1}\end{array}$ & $\% \operatorname{RSD}^{1, *}$ & $\begin{array}{l}\text { Recovery, \% } \\
(625 \mathrm{ng} / \mathrm{mL})^{2}\end{array}$ & $\begin{array}{c}\text { Recovery, \% } \\
(25.000 \mathrm{ng} / \mathrm{mL})^{2}\end{array}$ \\
\hline Glycine & 108.3 & 3.9 & 65.6 & 72.4 \\
\hline Alanine & 104.7 & 3.2 & 82.8 & 85.4 \\
\hline Valine & 106.4 & 3.3 & 92.3 & 95.0 \\
\hline Leucine & 107.9 & 3.6 & 81.5 & 86.6 \\
\hline Isoleucine & 106.7 & 3.5 & 91.8 & 95.8 \\
\hline Methionine & 109.1 & 3.4 & 80.0 & 79.5 \\
\hline Proline & 105.6 & 3.5 & 86.9 & 85.6 \\
\hline 4-hydroxy proline & 97.5 & 2.6 & 72.1 & 79.1 \\
\hline Serine & 107.2 & 3.3 & 84.1 & 86.0 \\
\hline Threonine & 107.2 & 3.9 & 89.1 & 90.5 \\
\hline Lysine & 108.1 & 3.4 & 86.2 & 88.0 \\
\hline Arginine & 104.1 & 4.3 & 88.9 & 85.0 \\
\hline Histidine & 106.9 & 5.2 & 92.2 & 95.8 \\
\hline
\end{tabular}

${ }^{1}$ Spike-in of $12.500 \mathrm{ng}$ of each amino acid into a solution of hydrolyzed $\alpha$-lactalbumin, $n=5 .{ }^{2}$ Recovery after hydrolysis of standards at two concentration. * Relative standard deviation in percent (\%RSD).

\subsubsection{Comparison of Hydrolysis in Glass Capillaries and Vacuum Hydrolysis Tubes}

Finally, we compared two methods of hydrolysis, using either glass capillary tubes or vacuum hydrolysis tubes. For all method validations in this paper that involved hydrolysis, the hydrolysis was performed in glass capillary tubes. As the inner diameter of these tubes is only $2.35 \mathrm{~mm}$, these tubes are ideal for the hydrolysis of small volumes of liquid. However, many solid sample types, like food and feed substances, are not easily inserted into these tubes. As an alternative to glass capillary tubes, vacuum hydrolysis tubes ( $1 \mathrm{~mL}$, ThermoFisher Scientific, Waltham, MA, USA) was used, which are ideal for the hydrolysis of larger volumes or solid samples. Therefore, we compared L- and D-amino acid analysis of a sample, hydrolyzed in either glass capillary tubes or vacuum hydrolysis tubes. For this purpose, we hydrolyzed a protein concentrate (powder) from the plant; lucerne (alfalfa).

In Table 5, the concentration of the individual L- and D-amino acids in protein concentrate from lucerne is shown, both from hydrolysis in glass capillary tubes and from hydrolysis in vacuum hydrolysis tubes. With a few exceptions, the \%RSD for the hydrolyzed samples was lower than $7 \%$, and all $\%$ RSD values were $\leq 17.6 \%$. The average $\%$ RSD was higher for D-amino acids than L-amino acids $(7.9 \%$ and $4.3 \%$, respectively). The average \%RSD was slightly lower in glass capillary tubes than in vacuum hydrolysis tubes (5.5\% and $6.1 \%$, respectively).

The proportion of D-amino acids in lucerne was very low and did not exceed $0.62 \%$ for any amino acid. The average proportion of D-amino acids hydrolyzed in glass capillaries tubes was $0.30 \%$ D-amino acids in lucerne, relative to $0.25 \% \mathrm{D}$-amino acids when the hydrolysis was performed in vacuum hydrolysis tubes. 
Table 5. L- and D-amino acids in protein concentrate (powder) from lucerne.

\begin{tabular}{|c|c|c|c|c|c|c|c|}
\hline \multirow[t]{2}{*}{ Analyte } & & \multicolumn{2}{|c|}{ Capillary Tubes } & \multicolumn{2}{|c|}{ Vacuum Tubes } & \multirow{2}{*}{$\begin{array}{c}\begin{array}{c}\text { Capillary } \\
\text { Tubes }\end{array} \\
\begin{array}{c}\text { D-amino acid } \\
\text { in } \% \text { of total } \\
\text { amino acid }\end{array}\end{array}$} & \multirow{2}{*}{$\begin{array}{c}\begin{array}{c}\text { Vacuum } \\
\text { Tubes }\end{array} \\
\begin{array}{c}\text { D-amino acid } \\
\text { in } \% \text { of total } \\
\text { amino acid }\end{array}\end{array}$} \\
\hline & & $\begin{array}{c}\text { Average } \\
\left(\mathrm{ng} / \mathrm{mg} \mathrm{DM}^{* *}\right)\end{array}$ & $\% \mathrm{RSD}^{*}$ & $\begin{array}{c}\text { Average } \\
\left(\mathrm{ng} / \mathrm{mg} \mathrm{DM}^{* *}\right)\end{array}$ & $\% R_{S D}^{*}$ & & \\
\hline Glycine & & $11,119.6$ & 3.6 & $10,472.7$ & 7.0 & & \\
\hline \multirow[t]{2}{*}{ Alanine } & $\mathrm{L}$ & $18,478.9$ & 4.3 & $18,172.8$ & 3.7 & & \\
\hline & $\mathrm{D}$ & 66.4 & 4.6 & 60.8 & 4.8 & 0.36 & 0.33 \\
\hline \multirow[t]{2}{*}{ Valine } & $\mathrm{L}$ & $22,364.0$ & 5.3 & $22,624.5$ & 2.0 & & \\
\hline & $\mathrm{D}$ & 39.2 & 3.5 & 32.0 & 2.5 & 0.17 & 0.14 \\
\hline \multirow[t]{2}{*}{ Leucine } & $\mathrm{L}$ & $28,872.5$ & 4.8 & $30,204.3$ & 3.8 & & \\
\hline & $\mathrm{D}$ & 143.3 & 5.6 & 126.2 & 5.9 & 0.49 & 0.42 \\
\hline \multirow[t]{2}{*}{ Isoleucine } & $\mathrm{L}$ & $16,402.4$ & 5.8 & $17,320.4$ & 1.5 & & \\
\hline & $\mathrm{D}$ & 4.1 & 17.6 & 3.0 & 7.9 & 0.02 & 0.02 \\
\hline \multirow[t]{2}{*}{ Methionine } & $\mathrm{L}$ & 4396.9 & 4.7 & 3432.5 & 8.4 & & \\
\hline & $\mathrm{D}$ & 13.9 & 6.5 & 9.6 & 15.6 & 0.32 & 0.28 \\
\hline \multirow[t]{2}{*}{ Proline } & $\mathrm{L}$ & $15,622.6$ & 4.5 & $16,850.8$ & 3.9 & & \\
\hline & $\mathrm{D}$ & 60.6 & 4.7 & 62.2 & 12.7 & 0.39 & 0.37 \\
\hline 4-hydroxy proline & $\mathrm{L}$ & 535.6 & 3.6 & 563.3 & 4.1 & - & - \\
\hline Serine & $\mathrm{L}+\mathrm{D}$ & $17,225.9$ & 5.0 & $17,518.5$ & 3.3 & - & - \\
\hline \multirow[t]{2}{*}{ Threonine } & $\mathrm{L}$ & $13,895.4$ & 5.6 & $14,061.0$ & 3.6 & & \\
\hline & $\mathrm{D}$ & 10.0 & 6.8 & 8.5 & 15.2 & 0.07 & 0.06 \\
\hline \multirow[t]{2}{*}{ Lysine } & $\mathrm{L}$ & $20,940.4$ & 5.9 & $23,151.2$ & 2.8 & & \\
\hline & $\mathrm{D}$ & 129.3 & 2.7 & 98.4 & 17.3 & 0.61 & 0.42 \\
\hline \multirow[t]{2}{*}{ Arginine } & $\mathrm{L}$ & $22,703.1$ & 5.2 & $23,643.8$ & 4.2 & & \\
\hline & $\mathrm{D}$ & 72.3 & 4.6 & 61.9 & 4.1 & 0.32 & 0.26 \\
\hline \multirow[t]{2}{*}{ Histidine } & $\mathrm{L}$ & $10,377.1$ & 5.5 & $10,910.0$ & 2.5 & & \\
\hline & $\mathrm{D}$ & 25.7 & 5.9 & 20.8 & 4.0 & 0.25 & 0.19 \\
\hline
\end{tabular}

\section{Discussion}

In the development of our method for the simultaneous determination of the L- and D- amino acid composition in complex biological samples, we modified the LC-MS methods from previous publications on the analysis of free D-amino acids in body fluids [15] and tissue [16,17]. As most proteins consist of L-amino acids with very low concentrations of D-amino acids, a sensitive method combined with a wide mass range of analysis was required. In contrast to the previously published methods, we needed a much wider range of analysis in order to cover the large dynamic range of L- and D-amino acids in natural protein samples. D-amino acids appear in the low part of the analytical range (in lucerne: 3-144 ng/mL), whereas L-amino acids appear in a high range (in lucerne: $3500-30,000 \mathrm{ng} / \mathrm{nL}$ ). If a single standard curve was applied over the entire analytical range, a relatively small alteration in the highest calibration points would have a large effect in the low calibration range. A more accurate quantification was made when the standard curves are split in two. Therefore, we generated two calibration curves spanning from 0 to $1250 \mathrm{ng} / \mathrm{mL}$ and 1250 to $50,000 \mathrm{ng} / \mathrm{mL}$, respectively. Consequently, in our case, the slopes of the low range curves are a little lower than for the high range curve of the same analyte. Utilizing these calibration curves in combination with the dilution of samples (for the analysis of L-amino acids) allowed us to quantify low levels of D-amino acids in combination with high levels of L-amino acid, using the same analytical method. For an illustration of the large dynamic range required, see Figure 1 of the analysis of pure L-histidine standard before and after hydrolysis in $\mathrm{HCl}$. Here, we show that the L-histidine standard contains $0.07 \%$ D-histidine and that a standard $\mathrm{HCl}$ hydrolysis of the same sample generates more than $10 \%$ D-histidine, supporting previous findings on hydrolysis induced racemization $[18,19]$. 


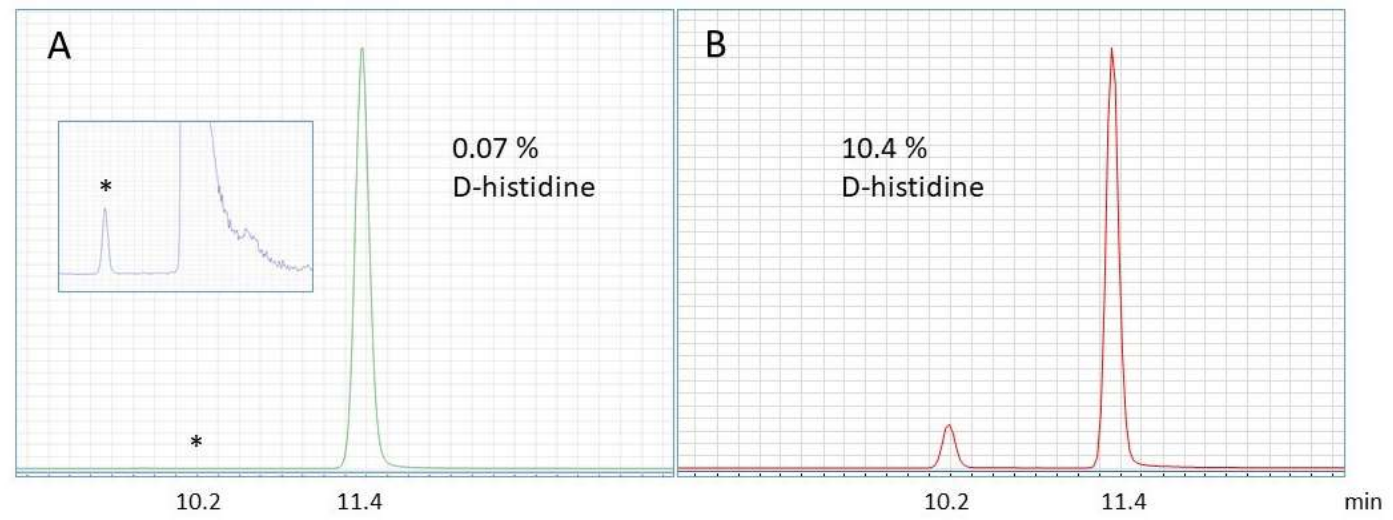

Figure 1. MRM spectrum of pure L-histidine standard. (A) L-histidine before hydrolysis contains $0.07 \%$ D-histidine. (B) L-histidine after hydrolysis in $6 \mathrm{M} \mathrm{HCl}$ contains $10.4 \%$ D-histidine.

We observed a background signal from phenylalanine, which most likely derives from the chiral derivatization agent (S-NIFE) that holds phenylalanine in the chemical structure. From personal communication with Dr. Koning [15], we learned that they experienced similar problems and observed a large batch to batch variation of phenylalanine in S-NIFE. In their paper [15], the background signal from phenylalanine was reduced by the recrystallization of S-NIFE. However, this approach was not successful in our hands. As a consequence, we were unable to establish a linear phenylalanine calibration curve for calibration points below 12,500 ng/mL. A possible solution could be to synthesize another derivatization agent, which is based on a non-proteogenic amino acid instead of phenylalanine. Furthermore, as reported by Visser et al. [15], we observed that lysine and tyrosine reacted with two molecules of S-NIFE.

When analyzing amino acids in intact food protein, in contrast to free amino acids, protein hydrolysis is required. Chemical hydrolysis (acid or alkaline) will result in a (partial) racemization of the amino acids, where L-amino acids are converted to D-amino acids and vice versa [22]. The degree of racemization depends on hydrolysis conditions, including temperature, pressure, time and chemical composition of the hydrolysis solution, as well as the individual amino acids [2,3,22]. Therefore, analysis of the L- and D-amino acid composition of hydrolyzed samples may be biased. The fraction of $\mathrm{D}$-amino acids is overestimated in samples predominantly consisting of L-amino acids, as more L-amino acids than D-amino acids will racemize. This is illustrated in Figure 1, which shows the analysis of a pure L-histidine standard before ( $0.07 \%$ D-histidine) and after (10.4\% D-histidine) hydrolysis with $\mathrm{HCl}$. To overcome this issue, hydrolysis can be performed under deuterated conditions, using $\mathrm{DCl}$. If an amino acid racemizes, a hydrogen-deuterium exchange will occur on the alpha carbon of the amino acid $[19,20]$. Consequently, racemized amino acids will increase $+1 \mathrm{Da}$ in mass, and will therefore not contribute to the MRM analysis of the amino acid (for an illustration of the chemistry, see [19]). Therefore, when using this hydrogen-deuterium exchange method, the correct ratio between $\mathrm{L}$ - and D-amino acids (before hydrolysis) is measured. $\mathrm{DCl}$ hydrolysis of peptides and proteins have previously been applied in different analytical set-ups, including for the identification of D-amino acid-containing neuropeptides [23].

We evaluated the hydrolysis method and found a minor matrix effect of hydrolyzed protein (4.1\%-9.1\% overestimation). In contrast, recovery after protein hydrolysis was approx. $80 \%-90 \%$. Fortunately, the underestimation of the absolute quantification is partly canceled out by the matrix effect of hydrolyzed protein. More importantly, as racemization occurs evenly among L- and D-amino acids, the ratios between the enantiomers are not biased by acid hydrolysis. In the analysis of food and feed quality, it is the ratios between L- and D-amino acids, rather than the absolute values, that are important. A high D-amino acid fraction in food or feed has a negative impact on nutritional value.

Acid hydrolysis is well known to be destructive to some amino acids [24], observed as deamidations (asparagine and glutamine) and oxidations (tryptophan and tyrosine). Therefore, aspartic acid and 
glutamic acid are often measured as the sum of both the acidic and the amide form. Oxidation can be minimized by the addition of phenol and mercaptoethanol. Unfortunately, in our set-up involving both DCl hydrolysis and S-NIFE derivatization, quantification that met the validation criteria could not be obtained for these amino acids and they were excluded from the analysis of hydrolyzed samples. However, the compounds were kept in the validation prior to hydrolysis, as the method also can be applied for the analysis of free amino acids.

Finally, we compared two methods of hydrolysis, using either glass capillary tubes or vacuum hydrolysis tubes. Whereas glass capillary tubes are ideal for a small volume of liquid, vacuum hydrolysis tubes are needed for hydrolysis of larger volumes or solid samples. In the analysis of a protein concentrate (powder) from the plant; lucerne (alfalfa), we found that the proportion of D-amino acids in lucerne was very low ( $\leq 0.62 \%$ for any amino acid). The average \%RSD was higher for the analysis of D-amino acids than L-amino acids (7.9\% and $4.3 \%$, respectively) indicating that the precision of the method decreases a little at very low concentrations. Serine has the lowest difference in retention time between all the analyzed L- and D-enantiomers. The low retention time in combination with a very low proportion of D-serine in lucerne meant that the two enantiomers could not be distinguished in this analysis. However, in the analysis of other material with higher D-serine levels, the two compounds were successfully distinguished (data not shown).

Industrial processing or fermentation can lead to an increase in D-amino acid levels in food and feed proteins [1-4]. Consequently, the digestibility and bioavailability of these proteins decrease. So far, the determination of the $\mathrm{L}$ - and $\mathrm{D}$-amino acid composition in proteins has been challenging, due to the need for either alkaline or acetic hydrolysis. Sample hydrolysis generates racemization, which in general leads to an overestimation of D-amino acids.

Here, we present a validation of an LC-MS/MS-based method for the simultaneous determination of L- and D-amino acids in complex biological matrixes, like food and feed. The use of deuterated $\mathrm{HCl}$ for sample hydrolysis eliminated a racemization-induced bias in the L- and D-amino acid ratios. We have adapted this method for the analysis of both small volumes of liquid and for solid samples, such as food. The method was applied to the analysis of a green protein isolate from lucerne, which is a potential alternative protein source with a low climate impact.

\section{Conclusions}

We have developed a method for the simultaneous determination of L- and D-amino acids in proteins. Previously, LC-MS/MS methods have been developed for quantification of free D-amino acids using S-NIFE derivatization. We have adapted this approach for a precise determination of the Land D-amino acid ratios in complex protein matrixes, such as food and feed. Importantly, hydrolysis induced biases introduced during sample preparation was eliminated by hydrogen-deuterium exchange. The method was applied to the analysis of a protein extract from lucerne, which contained an average of $0.3 \%$ D-amino acids.

Author Contributions: Conceptualization, T.K.D. and M.D.; methodology, M.D and C.N.; validation, M.D. and C.N.; formal analysis, M.D.; investigation, M.D. and C.N.; resources, T.K.D.; data curation, C.N. and M.D.; writing - original draft preparation, M.D.; writing—review and editing, T.K.D. and M.D.; visualization, M.D.; supervision, T.K.D.; project administration, T.K.D.; funding acquisition, T.K.D. All authors have read and agreed to the published version of the manuscript.

Funding: This research received no external funding.

Conflicts of Interest: The authors declare no conflicts of interest. The funders had no role in the design of the study; in the collection, analyses, or interpretation of data; in the writing of the manuscript, or in the decision to publish the results. 


\section{References}

1. Jasour, M.S.; Wagner, L.; Sundekilde, U.K.; Larsen, B.K.; Rasmussen, H.T.; Hjermitslev, N.H.; Hammershøj, M.; Dalsgaard, A.J.T.; Dalsgaard, T.K. Fishmeal with different levels of biogenic amines in aquafeed: Comparison of feed protein quality, fish growth performance, and metabolism. Aquaculture 2018, 488, 80-89. [CrossRef]

2. Csapó, J.; Albert, C. The D-amino acid content of foodstuffs (A Review). Acta Univ. Sapientiae Aliment. 2009, 2, 5-30.

3. Csapó, J.; Varga-Visi, É.; Lóki, K.; Albert, C.; Salamon, S. The influence of extrusion on loss and racemization of amino acids. Amino Acids 2008, 34, 287-292. [CrossRef] [PubMed]

4. Gilani, G.S.; Xiao, C.W.; Cockell, K.A. Impact of antinutritional factors in food proteins on the digestibility of protein and the bioavailability of amino acids and on protein quality. Br. J. Nutr. 2012, 108 (Suppl. S2), S315-S332. [CrossRef] [PubMed]

5. Hayase, F.; Kato, H.; Fujimaki, M. Racemization of amino acid residues in proteins and poly (L-amino acids) during roasting. J. Agric. Food Chem. 1975, 23, 491-494. [CrossRef]

6. Friedman, M.; Gumbmann, M.R.; Masters, P.M. Protein-alkali reactions: Chemistry, toxicology, and nutritional consequences. Adv. Exp. Med. Biol. 1984, 177, 367-412.

7. Mutaguchi, Y.; Ohmori, T.; Akano, H.; Doi, K.; Ohshima, T. Distribution of D-amino acids in vinegars and involvement of lactic acid bacteria in the production of D-amino acids. Springerplus 2013, 2, 1-9. [CrossRef]

8. Miyoshi, Y.; Nagano, M.; Ishigo, S.; Ito, Y.; Hashiguchi, K.; Hishida, N.; Mita, M.; Lindner, W.; Hamase, K. Chiral amino acid analysis of Japanese traditional Kurozu and the developmental changes during earthenware jar fermentation processes. J. Chromatogr. B Anal. Technol. Biomed. Life Sci. 2014, 966, 187-192. [CrossRef]

9. Friedman, M.; Levin, C.E. Nutritional and medicinal aspects of D-amino acids. Amino Acids 2012, 42, 1553-1582. [CrossRef]

10. Bardaweel, S.K.; Rana, A.D.; Almomani, N.F. An in vitro based investigation into the cytotoxic effects of D-amino acids. Acta Pharm. 2013, 63, 467-478. [CrossRef]

11. Moubarac, J.-C.; Batal, M.; Martins, A.P.B.; Claro, R.; Levy, R.B.; Cannon, G.; Monteiro, C. Processed and ultra-processed food products: Consumption trends in Canada from 1938 to 2011. Can. J. Diet. Pract. Res. 2014, 75, 15-21. [CrossRef] [PubMed]

12. Pätzold, R.; Brückner, H. Mass spectrometric detection and formation of D-amino acids in processed plant saps, syrups, and fruit juice concentrates. J. Agric. Food Chem. 2005, 53, 9722-9729. [CrossRef] [PubMed]

13. Casado, F.J.; Sánchez, A.H.; Rejano, L.; Montaño, A. D-amino acid formation in sterilized alkali-treated olives. J. Agric. Food Chem. 2007, 55, 3503-3507. [CrossRef] [PubMed]

14. Stødkilde, L.; Damborg, V.K.; Jørgensen, H.; Lærke, H.N. White clover fractions as protein source for monogastrics: Dry matter digestibility and protein digestibility-corrected amino acid scores. J. Sci. Food Agric. 2018, 98, 2557-2563. [CrossRef] [PubMed]

15. Visser, W.F.; Verhoeven-Duif, N.M.; Ophoff, R.; Bakker, S.; Klomp, L.W.; Berger, R.; de Koning, T.J. A sensitive and simple ultra-high-performance-liquid chromatography-tandem mass spectrometry based method for the quantification of d-amino acids in body fluids. J. Chromatogr. A 2011, 1218, 7130-7136. [CrossRef] [PubMed]

16. Xing, Y.; Li, X.; Guo, X.; Cui, Y. Simultaneous determination of 18 d-amino acids in rat plasma by an ultrahigh-performance liquid chromatography-tandem mass spectrometry method: Application to explore the potential relationship between Alzheimer's disease and d-amino acid level alteration. Anal. Bioanal. Chem. 2016, 408, 141-150. [CrossRef]

17. Li, Z.; Xing, Y.; Guo, X.; Cui, Y. Development of an UPLC-MS/MS method for simultaneous quantitation of $11 \mathrm{~d}$-amino acids in different regions of rat brain: Application to a study on the associations of d-amino acid concentration changes and Alzheimer's disease. J. Chromatogr. B 2017, 1058, 40-46. [CrossRef]

18. Miyamoto, T.; Homma, H. Detection and quantification of d-amino acid residues in peptides and proteins using acid hydrolysis. Biochim. Biophys. Acta. Proteins Proteomics 2018, 1866, 775-782. [CrossRef]

19. Goodlett, D.R.; Abuaf, P.A.; Savage, P.A.; Kowalski, K.A.; Mukherjee, T.K.; Tolan, J.W.; Corkum, N.; Goldstein, G.; Crowther, J.B. Peptide chiral purity determination: Hydrolysis in deuterated acid, derivatization with Marfey's reagent and analysis using high-performance liquid chromatography-electrospray ionization-mass spectrometry. J. Chromatogr. A 1995, 707, 233-244. [CrossRef] 
20. Liardon, R.; Ledermann, S.; Ott, U. Determination of d-amino acids by deuterium labelling and selected ion monitoring. J. Chromatogr. A 1981, 203, 385-395. [CrossRef]

21. Adebiyi, A.P.; Jin, D.-H.; Ogawa, T.; Muramoto, K. Acid Hydrolysis of Protein in a Microcapillary Tube for the Recovery of Tryptophan. Biosci. Biotechnol. Biochem. 2005, 69, 255-257. [CrossRef] [PubMed]

22. Kaiser, K.; Benner, R. Hydrolysis-induced racemization of amino acids. Limnol. Oceanogr. Methods 2005, 3, 318-325. [CrossRef]

23. Livnat, I.; Tai, H.; Jansson, E.T.; Bai, L.; Romanova, E.V.; Chen, T.; Yu, K.; Chen, S.; Zhang, Y.; Wang, Z.; et al. Amino Acid-Containing Neuropeptide Discovery Funnel. Anal. Chem. 2016, 88, 11868-11876. [CrossRef] [PubMed]

24. Pickering, M.; Newton, P. Amino acid hydrolysis: Old problems, new solutions. Lc Gc 1990, 8, 778-781.

(C) 2020 by the authors. Licensee MDPI, Basel, Switzerland. This article is an open access article distributed under the terms and conditions of the Creative Commons Attribution (CC BY) license (http://creativecommons.org/licenses/by/4.0/). 